\title{
Children and Wards of Low Income Class and Access to University Education
}

\author{
Alfred Kuranchie \\ Faculty of Education, Catholic University College of Ghana, Fiapre-Sunyani, Ghana. \\ Email: kuranchiealf@yahoo.com
}

\section{Doi:10.5901/ajis.2013.v2n3p19}

\begin{abstract}
The liberalization of tertiary education has seen private universities outstripping the public universities in Ghana. The private sector is expected to augment the provision of tertiary education to service the masses with academic ability. The study set out to explore how the private universities were aiding to meet the ever rapidly growing demand for tertiary education in the country. It was conducted in one of the arguably best private universities in the country using $10 \%$ of its enrolment as a sample size. The evidence of the survey shows that private universities are playing a pivotal role in supplementing state's efforts in university education provisioning by offering opportunities for the poor also. The significance of the study is that it has provided baseline information on the private university's ability to augmenting the attempt to equalize access to university education in the country.
\end{abstract}

Keywords: University education, accessibility, socio-economic status, low income group and sponsors of university education.

\section{Introduction}

Higher education is arguably the single most important determinant of social transformation, facilitating modernization and social mobility (Adei, 2006). This level of education usually leads to higher earnings and economic and social mobility. It plays a very significant and an increasingly vital role in human, social and economic development of a nation (Escrigas, 2008). Higher education is directly linked to economic growth, development and poverty reduction. It confers important public goods that are essential to development and poverty reduction-goods that must be accessible to all strata, to all people, and to both men and women (World Bank, 2002). Higher education contributes to poverty reduction through the building and redistribution of social capital. Higher education works to redistribute social capital by opening up opportunities for better employment and income to "underprivileged" students and consequently reducing inequity. Growing access to higher education accompanies great promise for broadening opportunity and fostering upward mobility (Attwell \& Lavin, 2007). Tertiary institutions build knowledge, skills, attitudes and ethics that construct the social capital necessary for healthy civil societies, cohesive social cultures and democratic political systems (World Bank, 2002).

The norms, values, attitudes and ethics that tertiary institutions impart to students are the foundation of the social capital necessary for constructing healthy civil societies and cohesive cultures - the basis of good governance and democratic systems. The relevance of tertiary education prompted the call for developing countries to make equal access to tertiary education an important objective if such countries were to meet the demands of modern economies and attain sustainable human development (UNESCO, 1995). Both the well-to-do and the disadvantaged in society who wield intellectual capacity should have equal opportunity to tertiary education for both private and social returns. Accordingly, Article 26 of the Universal Declaration of Human Rights states that admission to higher education should be based on merit, capacity, efforts, perseverance and devotion by those seeking it (UNESCO, 1998). The article supports proactive strategies to enable special target groups such as indigenous people, cultural and linguistic minorities, disadvantaged groups living under occupation and those who suffer from disabilities have easy access to higher education (UNESCO, 1995). Ideally, there should not be discrimination in access to higher education on the basis of economic ability so that all those who have the academic capacity would be trained to contribute meaningfully to socio-economic and political development of nations for the benefit of all and sundry.

Although the provision of university education in Ghana pre-dates independence, the desire for it became high in the 1990's compared to any time in the history of the country. Tertiary education has been very essential for economic progress of Ghana but perhaps never more so than in the late $20^{\text {th }}$ century. In this era, higher education was recognised as very crucial to the social, economic and political development of the country. The renewed interest of the government in tertiary education was also due to its ability to produce adequate skilled human resources for socio-economic 
development and industrial transformation of the country (Nsiah-Gyabaah, 2011).

The Ghana's educational sector was also deregulated in consonance with the democratization trend in the African region (Bemile, (n.d). Furthermore, international institutions' policies for reform of higher education also professed that in order to meet the increased demand for higher education and to enhance equity of opportunity different systems of higher education such as public, private and non-profit ownership were necessary (UNESCO, 1998, World Bank, 2002). The World Bank (2002) in particular held the view that the insatiable demand for higher education could only be met by public and private providers and through cost-sharing. Obviously, the state's alone continuous provisioning of tertiary education was inadequate, at the time, to meet the quest for higher education in most countries. Consequently, attempts were made to widen access to tertiary education. A very promising means of attaining this desire was to allow the private sector to join in the provision of university education. It was realised that evolving different categories of tertiary institutions would broaden the scope of institutional choices within the tertiary sector and drastically reduce the pressure on state-own institutions and public resources.

\subsection{Private University Education in Ghana}

Private education is the administration of educational institutions by the private sector although regulation remains the responsibility of the state. Private universities are financed, managed and controlled by private bodies; they mostly accept fee-paying students. Ownership of private schools also takes several forms: individual, family, private company and church (Chimombo, Dzimadzi, Kunje, \& Lewin, 2005, Rose, 2005). Although affiliated to public institutions for purposes of quality assurance, private universities continue to function independent of state direct financial support (Mabizel, 2007). In Ghana, as in most jurisdictions, private universities are first affiliated with well established universities before accreditation is granted. The mentor university offers instructional supervision, quality and standard control, and mentorship including the award of its certificates, diplomas and degrees to the students of the affiliated university college. Granting of autonomy to a university college is contingent on the fulfillment of certain conditions. In Ghana, the National Accreditation Board (NAB) is responsible for the accreditation of both private and public tertiary institutions with respect to programme contents and standards. The National Council for Tertiary Education (NCTE), an agency of the Ministry of Education (MoE), also provides consultation on education policy for institutions and reports to government on the conditions of higher education in the country. The NAB, the NCTE and the mentor institutions ensure that high standards are maintained by the private universities in order to offer value for money services to their clienteles.

The beginning of the new millennium saw a rapid establishment of private universities, a situation which can aptly be described as private university boom in Ghana. There was a considerable growth in the private provision of university education over the period. The setting up of private university educational institutions was given impetus by the Article 25 (2) of the 1992 Constitution which explicitly protects the setting up of private education in the country. The provision in the constitution states, inter alia, "that individuals and groups could set up private schools without state contribution of any kind: every person shall have the right, at his own expense, to establish and maintain a private school or schools at all levels and of such categories and in accordance with such conditions as may be provided by law" (MoE/GES, 2001). By this endorsement, the private sector was empowered to extend basic, secondary and tertiary education to all people in every nook and cranny of the country.

Private sector participation in higher education provisioning in the country has been welcome. It has been recognised that the private universities are also market oriented and entrepreneurial and have fashioned academic programmes in response to the demand of the current knowledge economy and clients' work life preferences (Effah, 2003). Most academic programmes are run on morning, evening and weekend schedules to meet the convenience of workers desirous of accessing higher education while working. Most of the private universities also run part-time courses that are given the same weight as full-time programmes. These programmes provide opportunities to a large number of people who desire to have higher education but otherwise cannot do so on full time basis. Indeed, some of the private universities offer admissions twice (August and January) in an academic year in a bid to widen access to university education to as many as have the capacity for that level of education. This is a sharp contrast to the public universities in Ghana which do admissions only once a year. It is observed that private universities in Ghana are creative by making available to students a range of choices in academic programmes and they have introduced healthy competition to the public universities (Gadzekpo as cited in Leach, et al, 2008). The private universities have also integrated human development programmes into their academic courses which meet the human resource needs of the country (Aheto, 2010). Most of their courses are in response to the demands and challenges of the labour market. At the end of the $2012 / 13$ academic year, the private universities in the country were realised to admit $26 \%$ of the total university students 
in the country (Daily Graphic, 22/07/2013).

\subsection{Problem Statement}

In the late 1990's, the country experienced rapid increase in the numbers of qualified secondary school leavers as a result of the attempt by successive governments to meet the Education for All (EFA) agenda and the Millennium Development Goals (MDG's) on education. The intent and focus of these policies and the massification of education in the country placed immense pressure on the existing universities. The increase in enrolments in pre-tertiary institutions reflected in the numbers of students who sought access to university education. The question interested to many was whether the state owned universities alone could meet the growing social demand for university education in the country. The capacity of the five public universities in Ghana at the time did not commensurate with the growing qualified and suitable student population. The situation made private universities to flourish thus changing the terrain of university education in Ghana in recent times.

Some private universities in the country are providing innovative, demand-driving and cutting-edge programmes (Bemile, (n.d) to meet the dynamic and ever-changing needs of the Ghanaian society. Their mode of education delivering is very sophisticated and in tandem with the technological age. Modern technologies such as laptops, iPods, iPhones, and others for power point and other presentations are common in the private universities.

All these notwithstanding, the concern that has been raised by many is the impact and direction of a privatized university education on the disadvantaged in the country. Do the private universities also admit the have-nots to taste university education? Are the poor and the marginalized with the intellectually capability get the chance to enrol and complete private university education in Ghana? There appeared to be paucity of information on such issues in Ghana and the questions needed empirical based evidence. Consequently, the fundamental aim of the study was to ascertain the extent to which private universities were widening the opportunity for university education to the disadvantaged as well in the Ghanaian society.

\subsection{Socio-economic Status (SES) Theory}

The concept of socio-economic status refers to the graded hierarchy of social positions which can be described as a person's overall social position or standing in a society. Socio-economic status which is the relative standing of people in society is based on income, power, background and prestige (Woolfolk, 2004). It is the grouping of people with similar occupational, educational and economic characteristics (Santrock, 2004, APA, Task Force on SES, 2007). Hence, socioeconomic status can be indicated by such sub-concepts as employment status, educational attainment, income and wealth (Graetz, 1995a). People in high socio-economic status have access to society's scarce resources than those in low socio-economic status. Such high income groups have access to scarce and valued resources which puts them in a better position to educate their children and wards to the level of education that their academic ability can take them. Such groups of people have the capacity to meet huge financial obligations associated with their children's and wards' higher education which would pave way for their easy upward social mobility in future. The opposite holds true to those in the middle and low socio-economic status concerning their dependents' higher education and their social mobility. This underscores why some brilliant students from low income families sometimes abruptly terminate their education at the lower levels of the education echelon. Hence, socio-economic status then becomes a significant predictor of children's educational attainment and social mobility.

\section{Methodology}

\subsection{Design and Population}

The survey study gathered data from a private university students to ascertain their parents and guardians' socioeconomic standing and their financial capabilities to discover how far the private sector is aiding to expand accessibility of higher education to the low income class in the Ghanaian society. Socio-economic status in this study is a composite of sponsors' level of education, type of occupation, income level and type of residence. The measure of economic status was based on income and occupation while that of social status was based on educational attainment and residence. The study utilised only students who depended solely on parents or guardians for their university education. To qualify for inclusion in the sample, a student must not be in employment and be an income earner. Consequently, students on study 
leave, those combining schooling with work and those on scholarships did not pass for inclusion in the study.

\subsection{Sampling Techniques and Size}

Stratified, purposive and convenience sampling methods were employed to select the students in the private university. In all, 450 students (250 males and 250 females) were selected for the study. The sample size forms approximately $10 \%$ of the entire student population (4454) of the university (Vice-Chancellor's Report, Mrach 2013).

\subsection{Instrument and Data Analysis}

A Socio-economic Status of Parents Questionnaire (SSPQ) which had 10 items was designed to gather data on the socio-economic standing of sponsors of the students. The items on the instrument which were mainly closed ended were validated by experts in education and research. The descriptive statistical data were analysed through the use of the SPSS version 16.

\section{Results and Discussion}

\section{1 a) Sponsorship Type}

Table 1: Sponsors of Students' Education

\begin{tabular}{lcc}
\hline & Frequency & Percent (\%) \\
\hline Self & 12 & 2.7 \\
Mother only & 75 & 16.5 \\
Father only & 79 & 17.6 \\
Both parents & 225 & 50.0 \\
Others & 59 & 13.5 \\
\hline Total & $\mathbf{4 5 0}$ & 100 \\
\hline
\end{tabular}

The data in Table 1 demonstrate that majority of the students sampled for the study are sponsored by both parents. Both mothers and fathers pool their resources together to finance the education of their children at the university. It is observed that only $2.7 \%$ (12) of the students are sponsoring their own university education. A good number of them (59 or 13.5\%) are being sponsored by people other than their real parents. The other sponsors of the students' university education included philanthropists, aunts, uncles and cousins.

\section{2 b) Sponsors' Level of Education}

Table 2: Sponsors' Level of Education

\begin{tabular}{lcc}
\hline & Frequency & Percent (\%) \\
\hline None & 25 & 5.6 \\
Basic & 79 & 17.6 \\
Secondary & 92 & 20.4 \\
Tertiary & 223 & 49.5 \\
Others & 31 & 6.9 \\
\hline Total & $\mathbf{4 5 0}$ & $\mathbf{1 0 0}$ \\
\hline
\end{tabular}

An important determinant of social status of parents is the level of educational attainment. Hence, the study solicited for the level of education of those who sponsor the students' university education. The results in Table 2 show that the majority of the sponsors of the students' university education have attained tertiary education. Almost half (49.6\%) of the sample had sponsors who had pursued tertiary education. Approximately, $20 \%$ of them also have sponsors who had gone through secondary education. It is only $5.6 \%$ of the students whose sponsors had no formal education. The results meant that the number of sponsors who have attained higher education exceeds that of those who have attained other levels of education. 


\section{3 c) Sponsors' Occupation}

Table 3: Nature of Sponsors' Occupation

\begin{tabular}{lcc}
\hline & Frequency & Percent (\%) \\
\hline Full time & 331 & 73.6 \\
Part time & 55 & 12.2 \\
Retired & 53 & 11.8 \\
Searching & 11 & 2.4 \\
\hline Total & $\mathbf{4 5 0}$ & $\mathbf{1 0 0}$ \\
\hline
\end{tabular}

The nature of work of a person has a bearing on the remuneration he/she receives and one's financial capacity to educate a person in a private university. The study sought to ascertain the nature of occupations of students' sponsors. According to Table 3, the majority of the students' sponsors are in full employment and receive remuneration. The sponsors are in full time employment and earn income to enable them take care of the students' education. The few sponsors who either are in part time employment (55 or 12.2\%) or are retired (53 or 11.8\%) also receive some income for the education of the students in addition to other expenditures. The results show that it is only a handful of students (11 or 2.4\%) whose sponsors were not in employment at all and were searching for one.

\section{4 d) Business of Sponsors}

Table 4: Kind of Business of Sponsors

\begin{tabular}{lcc}
\hline & Frequency & Percent (\%) \\
\hline Manufacturing & 26 & 5.8 \\
Trading & 122 & 27.1 \\
Farming & 55 & 12.2 \\
Teaching & 101 & 22.4 \\
Health & 52 & 11.6 \\
Others & 83 & 18.5 \\
\hline Searching & 11 & 2.4 \\
\hline Total & $\mathbf{4 5 0}$ & $\mathbf{1 0 0}$ \\
\hline
\end{tabular}

Table 4 shows that the majority of sponsors (57.8\%) are in the non-formal sector of the economy (trading $27.1 \%$, farming $12.2 \%$ and others $18.5 \%)$. Of those who are in the formal sector, manufacturing constituted $5.8 \%$, teaching $22.4 \%$ and health $11.6 \%(38.8 \%)$. The results mean that less than $40 \%$ of the sponsors are assured of monthly incomes and can also access credit facilities to help finance the education of their children and wards. However, majority of the sponsors, by virtue of the nature of their business, may find it difficult to provide collateral and other demands by financial institutions for receiving credit facilities to help them fund their children's and wards' education. In the Ghanaian economy, these conditions serve as barriers to people in the informal sector to access credit for important ventures such as footing university education bill.

\section{5 e) Monthly Income of Sponsors}

Table 5: Monthly Income of Sponsors

\begin{tabular}{lcc}
\hline & Frequency & Percent (\%) \\
\hline Below GHC 200 & 26 & 5.8 \\
Between GHC 200-500 & 130 & 28.9 \\
Between GHC 500-1000 & 152 & 33.8 \\
Between GHC 1000-1500 & 86 & 19.1 \\
Between GHC 1500-2000 & 21 & 4.6 \\
Above GHC 2000 & 35 & 7.8 \\
\hline Total & $\mathbf{4 5 0}$ & $\mathbf{1 0 0}$ \\
\hline
\end{tabular}


The monthly income of the sponsors of the students was inquired since it is a major determinant of students' university enrolment. According to Table 5, the majority of sponsors receive less that GHC 1,000.00 (equivalence of \$500) a month. Thus, the majority of the sponsors earn low income and hence have low economic status. The majority's monthly money is about half of the semester fees of students in the university excluding students' stipend. It is only $21.6 \%$ of the sponsors who earn a relatively high income that can conveniently cater for private university education in the country.

\section{6 f) Residence Type}

Table 6: Type of Residence of Sponsors

\begin{tabular}{lcc}
\hline & Frequency & Percent (\%) \\
\hline Owned & 161 & 35.8 \\
Rented & 157 & 34.9 \\
Family & 85 & 18.9 \\
Without payment (official residence) & 47 & 10.4 \\
\hline Total & $\mathbf{4 5 0}$ & $\mathbf{1 0 0}$ \\
\hline
\end{tabular}

The last item in the study was to determine the nature of the residence of sponsors. The data in Table 6 demonstrate that only approximately $36 \%$ of sponsors own their own houses. Majority of them (64\%) live in apartments owned by others. The results demonstrate that $34.9 \%$ are renting the houses they reside in while $18.9 \%$ live in family houses. It is also realised that $10.4 \%$ of them reside in official residences. The results thus show that majority of the sponsors do not have their own houses either in their hometowns or where they work and it is an indicative that the financial standings of the sponsors are not high.

\section{Conclusions and Suggestions}

The paper attempted to gauge the extent to which the private universities are aiding the public ones to meet the rapidly growing social demand for university education by all classes of people in the Ghanaian society. After almost two decades of allowing private participation in university education provisioning, it was deemed necessary to assess the extent to which the private universities were aiding to widen access to university education in the economy. The evidence has shown that the private university has students from the upper, middle and low income brackets. A good percentage of the students do not belong to the upper class families. Although a high percentage of the students' sponsors are in full time employment, their remunerations are not high. Over half of the sponsors of the students' tertiary education do earn less than $\$ 500.00$ a month. A similar percentage of the sponsors also does not own houses and live in either rented apartments or family houses. These features demonstrate low income status. It flows from this that the university does not confine itself to only the wealthier members of the Ghanaian society. Some of the university's conditions are pro-poor and are favourable to the low and middle class families. This is in contradiction of the view that private universities are open to only the wealthiest and most elite students.

It is plausible to conclude that the private university has a mix of students of different income groups. The private sector is, therefore, helping to broaden access to university education to the people in the middle and low income brackets as well in the Ghanaian society. People from the low and middle income groups are also able to access education in the private university to enable them uplift themselves from their economic quagmire in future, ceteris peribus. A university degree is a sure way for the middle and low class families' prosperity that can overcome the effects of disadvantaged social origin.

It is suggested that further research need to be conducted to find out how such students are able to meet their financial obligations in order to complete their university education. The study could also be replicated in the other private universities in the jurisdiction to ascertain the national picture of the subject.

\section{References}

Adei, S. (2006). Higher education and nation building. Tenth Anniversary Lecture, UCEW, Mampong Campus-Ghana (April 4).

Aheto, J. (2010). Private universities gaining prominence. Ghana News Agency. 27th June, 2010.

Escrigas, C. (2008). "Forward" in GUNI Higher Education in the World 3. London: Palgrace Mcmillan.

American Psychological Association (APA), Task Force on SES (2007). Report on socio-economic status. Washington D. C.: APA

Attwell, P. and Lavin, D. E. (2007). Passing the torch: Does higher education for the disadvantaged pay off across generations? New 
York: Russel Sage Foundation.

Bemile, S. N. (n.d). Challenges of Private Universities in Ghana. Publications

Chimombo, J., Dzimadzi, C., Kunje, D. and Lewin, K. (2005). The development of private sector providers of educational services in Malawi: Panacea or problem? Zomba. Malawi: CERT.

Effah, P. (2003). Ghana. In D. Teferra and P. G. Altbach (eds). African higher education: An international reference book. Bloomington: Indiana University Press.

Graetz, B. (1995a). Perspectives on socio-economic status in Ainley, J., Graetz, B., Long, M. and Batten, M. Socio-economic status and school education. Canberra: Australian Government Publishing Service.

Leach, et al (2008). A profile of participation in higher education in Ghana and Tanzania. Working Paper 4.

Mabizel, M. (2007). Private surge amid public dominance in higher education: The African Perspective. Council for Development of Social Science Research in Africa. 5(2 \& 3), 15-38.

Ministry of Education/Ghana Education Service (MoE/GES) (2001). Report of the study on the constitutional and legal framework for the right to pre-tertiary education. Accra: Ministry of Education.

Nsiah-Gyabaah, K. (2011). The increasing demand for tertiary education in Ghana and female participation. Journal of Polytechnics in Ghana, 5(1), 49-68.

Rose, P. (2005). Privatisation and decentralisation of schooling in Malawi: Default or design? Compare, 35, 153-165.

Santrock, J. W. (2004). Child development. (10'th ed.). New York: McGraw-Hill

UNESCO (1995). Policy paper for change and development in higher education. Paris:

UNESCO.

UNESCO (1998). World declaration on higher education for the $21^{\text {st }}$ century: Vision and Action. Adopted by the World Bank conference on higher education. Paris.

Vice-Chancellor's Report (March, 2013). Vice Chancellor's Report and Statistics, $8^{\text {th }}$ Congregation. Sunyani: CUCG.

Woolfolk, A. (2004). Educational Psychology. (10th ed.). Boston: Allyn and Bacon.

World Bank (2002). Constructing knowledge societies: New challenges for tertiary education. Washington, D C: World Bank. 
